\title{
The Role of Tat Twam Asi Teachings in Leader Member - Exchange Mediated by Teamwork towards BUMDes Employee Performance in Buleleng Regency
}

\author{
I Ketut Sudarnaya ${ }^{1^{*}}$ \\ ${ }^{1}$ Program Study of Management, Sekolah Tinggi Ilmu Ekonomi Satya Dharma Singaraja, Indonesia \\ *)Corresponding author, e-mail: sudarnaya@gmail.com
}

Received May 05, 2021; Revised May 23, 2021

Accepted May 30, 2021;

Published Online May, 31 2021

\section{Conflict of Interest Disclosures:}

The authors declare that they have no significant competing financial, professional or personal interests that might have influenced the performance or presentation of the work described in this manuscript.

\begin{abstract}
The Law Number 6 of 2014 concerning Villages, gives enthusiasm for villages to initiate themselves by creating the spirit of "Building Village" then BUMDes is born as an independent business institution for rural communities and will be able to develop its potential, if BUMDes pays close attention to the performance of employees is one of the factors that play an important role in achieving organizational goals. The purpose of this study is to explain the effect of leader member-exchange (LMX) and teamwork as a mediating variable on employee performance, both direct and indirect effects. The results showed that leader member-exchange (LMX) has a positive and significant effect on employee performance, teamwork has a positive and significant effect on employee performance and teamwork is a partial mediator of the influence of leader member-exchange (LMX) on the performance of BUMDes employees in Buleleng Regency. This research can provide knowledge and understanding for stakeholders in implicating teamwork in the relationship between leaders and subordinates (LMX) in improving employee performance.
\end{abstract}

Keywords: Leader Member-Exchange, LMX, Teamwork Employee Performance

This is an open access article distributed under the Creative Commons 4.0 Attribution License, which permits unrestricted use distribution, and reproduction in any medium, provided the original work is properly cited. (C2017 by author

How to Cite: Sudarnaya, K. 2021. The Role of Tat Twam Asi Teachings in Leader Member - Exchange Mediated by Teamwork towards BUMDes Employee Performance in Buleleng Regency, BISMA the Journal of Counseling, VV (N): pp. XXXX, DOI: 10.24036/XXXXXXXXXX-X 


\section{Introduction}

Performance management is a continuous cycle in improving performance by setting goals, feedback, rewards and positive reinforcement (Kreitner and Kinicki, 2010). Hasibuan, (2013), explains that performance is the result of work achieved by a person in carrying out the tasks assigned to him based on quantity, quality, time and cooperation. Likewise with BUMDes in Buleleng Regency as an independent business institution for village communities and a support or strengthening of the village economy is considered to be able to develop its potential, if BUMDes pay close attention to employee performance which is one of the factors that plays an important role in achieving organizational goals and individual goals. Optimal employee performance is a description of the quality that reflects the success of an employee which will result in increased overall performance.

To improve the quality and quantity of BUMDes in Buleleng Regency can develop and become an economic institution for rural communities that are competitive in managing and running economic machines in rural areas, a leader who understands the conditions and character of the local community is required, where a good leaders is expected to be able to build cooperation between the employees and can improve employee performance. One thing that leaders must pay attention to is the quality of the leader's relationship with his subordinates. The theory that regulates the relationship between leaders and subordinates is called the Leader Member Exchange or what is known as the LMX, where there is a twoway relationship of a relational leader.

Wayne and Ferris, (2012) stated that there was an insignificant relationship between LMX and employee performance. One of the antecedents is that conflicting research results show an insignificant relationship between LMX and employee performance due to the influence of situational factors, such as different values, personality, experience, organizational context and employee background. Therefore, it is necessary to accommodate individual and organizational factors in explaining the effect of LMX on employee performance. Several studies have shown that there is a mediating variable that is appropriate and relevant to the implementation of LMX, namely teamwork.

Teamwork can improve employee performance (Manzoor, et al., 2011). Research by Delarue, et.al. (2007) also shows that teamwork has a positive effect on all dimensions of employee performance. Teamwork has a significant relationship to employee performance (Agwu, 2015). High organizational performance is directly associated with effective teamwork. In good teamwork, the members can improve their skills, knowledge and abilities. Emphasis on teamwork can improve employee performance, increase productivity and solve problems at work (Agwu, 2015). Hooper and Martin, (2008) found that differences in the relationship between LMX and individual performance had a positive effect on team conflict. Erdogan and Bauer (2010) revealed that differences in the relationship between leaders and subordinates (LMX) are negatively related to colleagues but positively related to behavior when the climate of justice is low in teamwork. With regard to the results at the team level level of teamwork, the LMX differences are not directly related to teamwork, (Le Blanc \& Gonzales-Roma, 2012).

Based on some of the research results above, it appears that there is still a contradiction in the results of research on LMX and teamwork on employee performance. This is because LMX only analyzes exchange relationships in work-related tasks, while other dimensions that affect the relationship between leaders and subordinates have not been widely used in study. In this context, it relates to teamwork which can be used as a trigger in improving employee performance.

So in this research it is seen that it can provide its own color and repertoire in the scientific context related to the field of leadership science. Therefore it is necessary to study to obtain clarity on the Leader Member Exchange (LMX) theory mediated by teamwork towards employee performance at Village-Owned Enterprises. 


\section{Literature Review}

Performance is a condition that must be known and confirmed to certain parties to determine the level of achievement of an agency's results related to the vision carried by an organization or company and to know the positive and negative impacts of an operational policy. That performance is a function of effort and abilities. Furthermore Walker, (2010) states that variables that affect performance and can be controlled by management include: work design (tasks or activities that must be completed), job content, organizational context (for example: work organizational supervision style, physical conditions of the work place), conversion (reward / reward, working time and so on), performance objectives (performance targets). All of these variables have a direct effect on the level of individual effort in carrying out their job duties. Another important variable is individual competence. A hard worker, without the support of the necessary skills, cannot be expected to produce good performance.

Thus, an employee will have a high level of performance if there is a match between work and abilities. If these things are fulfilled, there will be a feeling of responsibility for their work and a willingness to participate in achieving organizational goals through the maximum implementation of tasks. Therefore organizations need to pay attention to human resource management to produce high performance in order to improve overall organizational performance (Taurisa and Ratnawati, 2012).

LMX theory is a reciprocal relationship that involves communication between leaders and subordinates through intimacy between one another, contributing to each other, being loyal and having respect between individuals. The relationships established by each subordinate and leader certainly differ from one another. Truckenbrodt, (2000) says that in an organization, seen from the relationships and interactions between leaders and subordinates can be grouped into two groups, namely: In-group: Subordinates and leaders have a good relationship, the relationship between the two is based on feelings of the same fate, trust, and affection for each other. This group is made up of team members that the leader trusts each other. Out-group: Leaders towards subordinates are more professional. This is because there is so little time provided to get closer, so that subordinates have less time for the leader, and the relationship between the two is only in the corridor of normal authority interactions.

Stephen and Timothy, (2013) state that teamwork is a group whose individual efforts result in higher performance than the amount of individual input. Teamwork generates positive synergy through coordinated efforts. In line with the theory presented by Smither, Houston, Mc-Intire, (2016) about an effective team theory that a team that allows its members to be able to complete a larger number of tasks than the work of individuals because their work results are the result of members' contributions. - team members together. This statement is also supported by Burn, (2014) which states that the effectiveness of an effective team or team is a work team whose members collaborate with each other to achieve common goals and have a mutually supportive attitude in teamwork.

This research is a development and assessment of the relationship of the influence of the Leader Member Exchange (LMX) and employee performance mediated by teamwork. This study develops a research conceptual framework as figure 1 . 


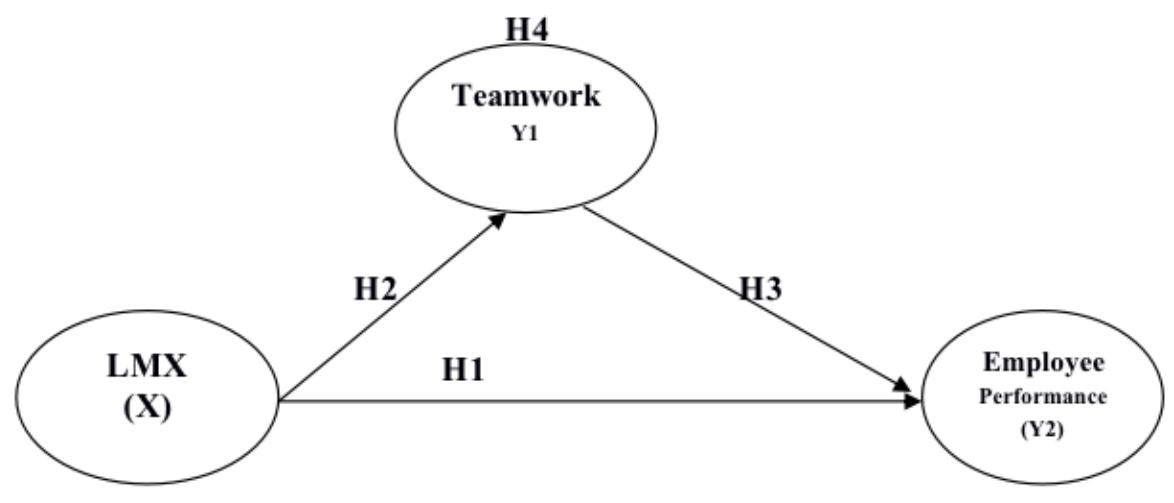

Figure 1.

\section{Conceptual Research Framework}

The relationship between the variables in the study is based on previous studies and is used as a basis in the preparation of research hypotheses, so this study proposes the following hypotheses:

Hypothesis 1: Leader Member Exchange (LMX) has a positive and significant effect on employee performance

Dulebohn, et al., (2012) high-quality LMX relationships are based on a trusting relationship between leaders and subordinates, with leaders who believe in their subordinates to be involved in important activities, have a sense of mutual obligation to each other's responsibilities, mutual respect each other, as well as providing good feedback between leaders and subordinates. While a low-quality Leader Member Exchange (LMX) relationship is characterized by an economic exchange relationship that rarely meets the leader, and subordinates are often assigned unwanted tasks, leaders have less time for their subordinates, resulting in subordinates having less closeness to their leader. Research conducted by Walumba, et al., (2011) and Choy, Mc-Comarck, (2010) explained that LMX has a positive effect on employee performance. Employees have sufficient resources at work, when these employees have a high exchange rate with their leaders and feel involved in a job. Wang, (2016) stated that

Hypothesis 2: Leader Member Exchange (LMX) has a positive and significant effect on teamwork.

Le Blanc \& Gonzales-Roma, (2012). In connection with the results at the teamwork level that the Leader Member Exchange (LMX) or the relationship between leaders and subordinates is directly related to teamwork. Liden. et al., (2006) revealed that there is no main effect of LMX differences on team performance but the same effect is significant when teamwork has high interdependence in carrying out tasks. The quality of the LMX relationship is perceived by team members as a conduit through which they receive tangible resources, for example: a raise or a job promotion, and intangible benefits, such as psychological support or emotional comfort, from their leader. (Graen and Uhl-Bien, 1995).

Hypothesis 3: Teamwork has a positive and significant effect on employee performance

Teamwork provides greater participation, challenges and achievements. Manzoor, et al., (2011) said that teamwork can improve employee performance. The team is an important part of the company, the company must be able to connect between individual and team work goals, clear communication and support 
for feedback and recognition of team members' performance can ensure a successful team work. Emphasis on teamwork can improve employee performance, increase productivity and solve problems at work (Agwu, 2015).

Hypothesis 4: Teamwork mediates the influence of leader member exchange (LMX) on employee performance

Teamwork is able to mediate the relationship between the leader and his subordinates Leader Member Exchange (LMX) on employee performance (Thamhain, 1990). Wayne, et al., (2002) LMX relationships vary in quality from low to high, and LMX quality varies across leaders and subordinates. This difference in LMX has an impact on the diversity of employee performance, so that teamwork is needed because of the interdependence between employees and each other in the form of information, materials and expertise to complete their work. Boies and Howell, (2006) tested the effect of LMX on teamwork as an important mediator of employee performance diversity. The result is that the difference between LMX and teamwork is positively related to employee performance.

\section{Method}

This research is designed to answer the problems that have been formulated in the formulation of the problem and use the research design as follows; based on the existing problems, this research is causal. The method used in this study is a survey method, which collects information from the existing population. Data collection was carried out in stages. This research design uses a positivist approach (quantitative), which leads to empirical rational principles with explanatory research type. To ensure the feasibility of each question in the questionnaire, it is necessary to test the validity and reliability. Thus the quantitative approach will be able to prove the hypotheses submitted by statistical techniques (Maholtra, 2004).

\section{Determination of Data}

This research will use two data sources related to the study and to obtain the desired results, while the data sources used are primary and secondary sources. The primary data of this research is data obtained directly from Village-Owned Enterprises (BUMDes) in Buleleng Regency. As for the primary data, the characteristics of the respondents (gender, age, and education) and answers to questionnaires distributed about leader member exchanges, teamwork and employee performance.

\section{Instrumentation}

The data in this study were collected by: (1) interviews, (2) documentation, (3) observation, making direct observations on BUMDes which became the research location and (4) questionnaires. Sugiyono, (2015) population is a generalization area consisting of objects and subjects that have certain qualities and characteristics that are determined by researchers to be studied and then draw conclusions. The population in this study were the BUMDes which were established from 2010 to 2015, namely as many as 73 BUMDes with a total of 537 employees. The sample is a part or representative of the population studied (Sugiyono, 2015). The number of research samples were some BUMDes employees in Buleleng Regency who were in each District using proportional random sampling, namely by taking 299 samples from 9 Districts in Buleleng Regency. Measurement of data in this study uses a Likert scale. The Likert scale is used to measure respondents' attitudes, opinions and perceptions of objects (Nasir, 2013).

\section{Data Analysis Technique}

From the data collected, the next step is to analyze the analysis. Descriptive analysis is used to describe the characteristics of respondents. From the collected data, the first test of the instrument used is the validity test with the Pearson Product Moment test (Gujarati, 2000), where the questions are declared valid 
with the provisions of $\mathrm{r}$ count $>$ from 0.3 with $\mathrm{df}=5 \%$. For the reliability test, it was carried out by looking at the Cronbach's Alpha value, which has a condition that if the Cronbach's Alpha value is $\geq 0.6$, the construct used is declared reliable (Hair et al., 2010).

Quantitative analysis based on multivariate analysis uses structural equation modeling or SEM (structural equation modeling) based on Partial Least Square (PLS). PLS is a powerful analytical method because it is not based on many assumptions. For example, the data must be normally distributed, the sample does not have to be large. Besides being able to be used to confirm the theory, PLS can also be used to explain whether there is a relationship between latent variables. PLS can simultaneously analyze the constructs formed by reflective and formative indicators.

The SEM-PLS used in this study was XLSTAT PLS which was carried out in two stages of evaluation, namely, (1) Evaluation of the Measures of Fit which was carried out by looking at the value of (a) Covergent validity (b) Discriminate validity, and (c) Composite reliability. (2) Evaluation of the structural model or Inner Model by looking at (a) Q-Square predictive relevance (Q2), (b) Effect size, (c) hypothesis testing and (d) mediation testing using the criteria of Hair et al. (2010). The mediation citeria as table 1.

Table 1 Mediation Criteria

\begin{tabular}{ccccc}
\hline \multirow{2}{*}{ No } & \multicolumn{3}{c}{ Mediation of Criteria Testing } & \multirow{2}{*}{ Remark } \\
\cline { 2 - 4 } & A & B & C & Significant \\
\\
\hline 1 & Significant & Significant & Partial Mediated \\
2 & Unsignificant & Significant & Significant & Fully Mediated \\
3 & & Unsignificant & Significant & Unmediated \\
4 & & Significant & Unsignificant & Unmediated \\
\hline
\end{tabular}

Source: Hair et al. (2010)

\section{Results and Discussion}

\section{Characteristics of Respondents}

The characteristics of the respondents used include gender, age, education and years of service. These four demographic aspects are assumed to have an important role in providing perceptions of employee performance. The characteristics of respondents based on gender were dominated by male employees as many as 124 people with a percentage of $54.1 \%$. Meanwhile, the characteristics of respondents based on age indicate that the largest proportion of employees is between 26 and 33 years old as many as 84 people with a percentage of $36.7 \%$. Furthermore, the characteristics based on education level are dominated by SMA / SMK education level with the composition seen in the SMA level education group, namely as many as 142 people with a percentage of $62.0 \%$ and SMK as many as 26 people with a percentage of $11.4 \%$ and the most dominant working period were respondents with a working period of 4 years to 6 years, namely as many as 119 people with a percentage of $52.0 \%$.

\section{Validity and Reliability Test}

The results of the instrument test carried out with the Pearson Product Moment show that all indicators are valid because the $\mathrm{r}$ value $>0.3$. Meanwhile, the reliability of all constructs was reliable because it had a Cronbach's Alpha value> 0.6. Covergent validity that is carried out showed that the indicators of each variable have an outer loading value of $>0.50$ (Ghozali, 2012). The results show that all indicators have a high level of validity, so that they meet the requirements of convergent validity. The model has better 
discriminant validity if the square root of AVE for each construct is greater than the correlation between the two constructs in the model. The results of data processing show that AVE shows the following teble 2 .

Table 2. Discriminan Validity Calculation Result

\begin{tabular}{lccccc}
\hline \multicolumn{1}{c}{ Variable } & AVE & AVE & \multicolumn{2}{c}{ Correlation Coefficient } \\
& \multicolumn{7}{c}{ Root } \\
& & & $\mathrm{X}$ & Y1 & Y2 \\
Leader Member Exchange (X) & 0,407 & 0,638 & $\mathbf{1 , 0 0 0 0}$ & 0,386 & 0,392 \\
Teamwork (Y1) & 0,535 & 0,743 & 0,386 & $\mathbf{1 , 0 0 0 0}$ & 0,510 \\
Employee Performance & 0,430 & 0,656 & 0,392 & 0,510 & $\mathbf{1 , 0 0 0 0}$ \\
(Y2) & & & & & \\
\hline
\end{tabular}

Based on the data conducted, it shows that the value of compositer reliability and cronbach's alpha> 0.70 so it can be concluded that the construct has good reliability because it meets the prerequisite is shows as table 3 .

Table 3. Composite Reliability and Cronbach Alpha Calculation Results

\begin{tabular}{lcc}
\hline \multicolumn{1}{c}{ Variable } & $\begin{array}{l}\text { Composite } \\
\text { Reliability }\end{array}$ & Cronbach Alpha \\
& & \\
\hline Leader Member Exchange (X) & 0,870 & 0,833 \\
Teamwork (Y1) & 0,889 & 0,854 \\
Employee Performance (Y2) & 0,892 & 0,866 \\
\hline
\end{tabular}

\section{Evaluation of the structural model or Inner Model}

The Q-Square predictive relevance calculated by the following formula;

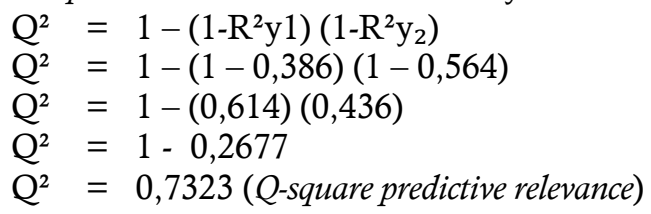

Table 4. Coefficient $\mathbf{R}^{2}$ Variable Communality

\begin{tabular}{lcc}
\hline \multicolumn{1}{c}{ Variable } & $\mathbf{R}^{\mathbf{2}}$ & Communality \\
& & \\
\hline Leader member-exchange (X) & 0,0000 & 0,407 \\
Teamwork (Y1) & 0,386 & 0,535 \\
Employee Performance (Y2) & 0,564 & 0,430 \\
\hline
\end{tabular}

From the teble 4, the results of the calculations performed show the predictive relevance Q-square value of 0.7323 , so that the model has a good predictive level. From the value obtained, it can be interpreted that as much as $73.23 \%$ of the influence between variables described in the model as a whole, while $(26.77 \%)$ is influenced by errors or other variables that are not explained or used in this research model. 
Goodness of Fit $(\mathrm{GoF})$ is used to validate the overall model, because it is a single measure of the measurement model (outer model) and the measurement of the structural model (inner model). The value of Goodness of Fit (GoF) ranges from 0 (zero) to 1 (one). The formula used to determine the Goodness of Fit (GoF) value is as follows:

$$
\begin{aligned}
& \text { GoF }=V \overline{c o m \times R^{2}} \\
& \text { GoF }=V\left\{\frac{(0,407+0,535+0,430)}{3} \times\left\{\frac{(0,386+0,564}{2}\right)\right\} \\
& \text { GoF }=V\left\{\frac{\left(\frac{1,372)}{3} \times\left\{\frac{(0,95)}{2}\right\}\right.}{\text { GoF }}=V\left\{\frac{(0,4573)\} \times\{(0,475)}{\text { GoF }}=V\left\{\frac{0,2172}{\text { GoF }}=0,4661\right.\right.\right.
\end{aligned}
$$

The results of the calculation of Goodness of Fit (GoF) show a value of 0.4661 , so based on the criteria regarding the GoF value according to Latan and Ghozali, (2013), among others: 0.10 (GoF small), 0.25 (moderate GoF), and 0.36 (GoF large), then the model formed by the constructs has a very large model category. Hair et al. (2013) state that the results of the effect size measurement can be grouped into three categories, namely weak with a value (0.02), moderate with a value $(0.15)$ and strong with a value $(0.35)$.

Table 5. Effect sizes for path coefficients

\begin{tabular}{lccc}
\hline Variable & $\begin{array}{l}\text { Leader Member } \\
\text { Exchange }\end{array}$ & Teamwork & $\begin{array}{l}\text { Employee } \\
\text { Performance }\end{array}$ \\
\hline Teamwork & 0,622 & 0 & 0,530 \\
Employee Performance & 0,297 & 0,530 & 0 \\
\hline
\end{tabular}

Based on Table 5, it can be seen that the effect size estimation results show the value of Leader MemberExchange (LMX) towards employee performance is (0.297), Teamwork towards employee performance is (0.530). This means that the Leader Member-Exchange (LMX) variable, teamwork has an estimated effect size in a strong category on employee performance. So that it can be explained that the Leader MemberExchange (LMX), teamwork has a very important role in improving employee performance. 


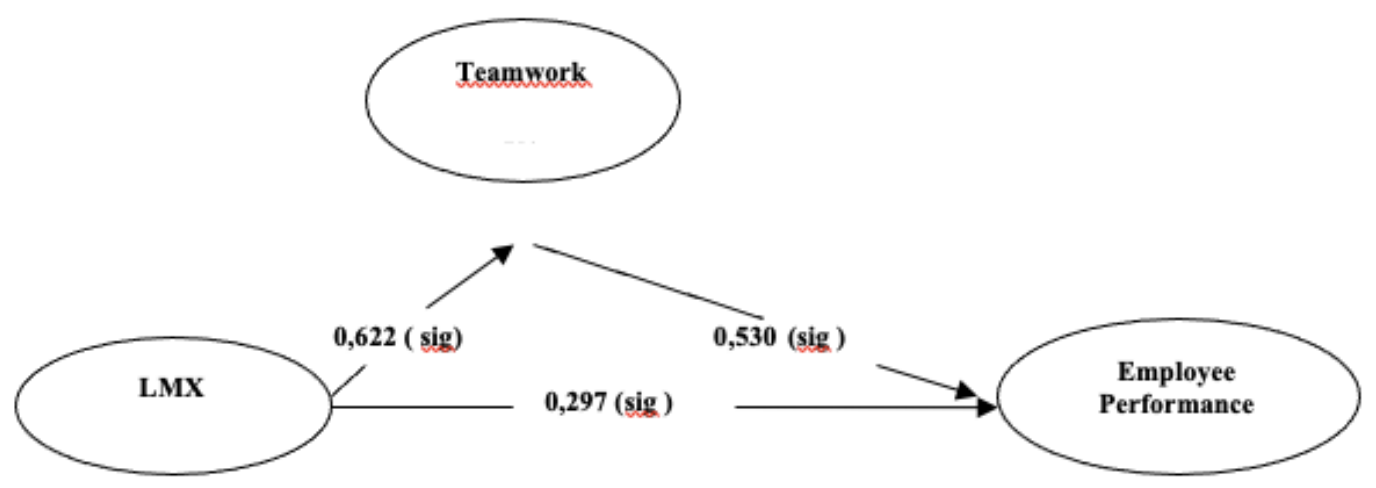

Figure 2. The Leader Member-Exchange (LMX) Empirical Model

\section{Hypotesis Testing}

The hypothesis testing aims to determine whether the proposed hypothesis is accepted or rejected. This study will test 7 (seven) hypotheses consisting of 5 (five) hypotheses which are a direct effect, 2 (two) hypotheses involving the mediating variable. Testing the relationship between variables in the model, it can be seen through the path coefficient of each relationship between variables, at the level of significance based on the t-statistic

Table 6. The results of hypothesis testing on the research model

\begin{tabular}{lcccc}
\hline $\begin{array}{c}\text { The Relationship Between } \\
\text { Variables }\end{array}$ & $\begin{array}{c}\text { Parth } \\
\text { Coefisient }\end{array}$ & $\begin{array}{c}\text { t- } \\
\text { Statistics }\end{array}$ & Sig & Remark \\
& & & & \\
\hline LMX (X) $\longrightarrow$ TW (Y2) & 0,622 & 11,957 & 1,96 & Significance \\
TW (Y2) $\longrightarrow$ EP (Y3) & 0,297 & 5,297 & 1,96 & Significance \\
LMX (X) $\longrightarrow$ EP (Y3) & 0,530 & 9,454 & 1,96 & Significance \\
\hline
\end{tabular}

Based on the results of data processing as presented in Table 6, the results of hypothesis testing can be described as follows. Hypothesis 1 which states that: LMX has a positive and significant effect on employee performance, is supported. These results indicate that the better the relationship between leaders and subordinates will be able to improve the performance of BUMDes employees in Buleleng Regency. Hypothesis 2 which states that: LMX has a positive and significant effect on teamwork, is supported. This result means that the higher the relationship between the leader and his subordinates, the higher the employee cooperation in teamwork for BUMDes employees in Buleleng Regency. Hypothesis $\mathbf{3}$ which states that: teamwork has a positive and significant effect on employee performance, is supported. This result means that the higher the employee cooperation, the higher the employee performance of BUMDes employees in Buleleng Regency.

\section{Mediation Testing}


Testing of the mediation variables aims to detect the position of the mediating variables in the research model. This is also done to determine the nature of the relationship between variables, either as a complete mediation or partial mediation, or not at all as a mediating variable. The method of testing the mediation variable used is the criteria of Hair, et al., (2010).

Table 7. Teamwork Mediation Testing towards the Influence of LMX on Employee Performance

\begin{tabular}{lll}
\hline The Relationship Between Variables & Significance & Remark \\
& & \\
\hline LMX (X) $\longrightarrow$ TW (Y2) & Significant & Partial \\
TW (Y2) $\longrightarrow$ EP (Y3) & Significant & \\
LMX (X) $\longrightarrow$ EP (Y3) & Significant & Mediation \\
\hline
\end{tabular}

From the table 7, it was found that teamwork is a partial mediation variable of the effect of LMX towards employee performance. The results of this analysis indicate that teamwork of BUMDes employees in Buleleng Regency has a role in helping leaders and subordinates (LMX) relationships in improving employee performance.

\section{Research Update}

In every study, it is always expected to offer useful updates in developing knowledge related to the field of employee performance studies. The novelty is offered because so far the leader member-exchange (LMX) has only analyzed the exchange relationship in work-related tasks, while other indicators that affect the relationship between leaders and subordinates (LMX), namely teamwork, have not been much studied.

Leader Member-Exchange (LMX) has a positive and significant influence towards employee performance mediated by teamwork, this shows that in improving the performance of BUMDes employees in Buleleng Regency, leaders and subordinates should continue to develop teamwork to improve employee performance.

\section{Conclusion}

Leader Member-Exchange (LMX) affects the employee performance of BUMDes in Buleleng Regency. And teamwork that is reflected by cooperation, trust and cohesiveness can improve employee performance. Teamwork partially mediates (partial mediation) between the leader member-exchange (LMX) and employee performance towards the performance of BUMDes employees in Buleleng Regency.

\section{References}

Agwu, MbaOkechukwu. (2015). Teamwork and Employee Performance in The Bonny Nigeria Liquefied Natural Gas Plant. Strategic Management Quarterly. Vol.3 No.4 Pp. 39-60. 
Albrecht, Simon L. (2015). Work Engagement and The Positive Power of Meaningfull Work, an Advances In Positive Organizational Psychology. Emerald Group Publishing Limited, Bingley, England. Volume 1. No. 5. pp. 237-260.

Arikonto, Suharsini, (2013). Prosedur Penelitian Suatu Pendekatan Praktek. Jakarta. Renika Cipta.

Arsintadiani, D., \& Harsono, M. (2002. Pengaruh Tingkat LMX Terhadap Penilaian Kinerja dan Kepuasan Kerja Dengan Kesamaan Gender dan Locos of Control Sebagai Variabel Moderator. Jurnal Perspektif, Volume 7 Nomor 2 Pp. 113-122.

As'ad, M. (2010). Kepemimpinan Efektif Dalam Perusahaan. Ediasi Ke-2 Liberty, Yogyakarta

Berdicchia, Dominico. (2015). The Relationship Bettween LMX and Performance : The Mediating Role of Role Breadth Self Efficacy and Craffting Chalenging Job Demand. Impresa Progeto Journal of Management Vol. 77 No.30 Pp.754-770.

Bjorne Grimsrud, Torunn Kvinge. (2006). Pruductivity Puzzles-Should Employee Participation Be an Issue?. Nordic Journal of Political Economy. Volume 32. No. 5 Pages 139-167.

Casimir, G., Ng, Y. N. K., Wang, K. Y., \& Ooi, G. (2014) The relationship amongst leader-member exchange, perceived organizational support, affective commitment, and in-role performance, Leadership \& Organization Development Journal, Vol.35: Pp. 366-385.

Cushway, Barry. (2013). Human Resources Management. Perencanaan Analisis Kinerja. Cetakan Ketiga. PT. Gramedia. Jakarta.

DeConinck, J. B. (2011). The effects of leader-member exchange and organizational identification on performance and turnover among salespeople. Journal of Personal Selling \& Sales Management, 31(1), 21-34.

Donny Sutanto Tan, Eko Harry Susanto. (2017). Pengaruh LMX dan Teamwork Terhadap Kinerja Karyawan. Jurnal manajemen Bisinis dan Kewirausahaan Volume 1. Nomor 2. Hal. 10-25

Dulebohn, J.H., Bommer, W.H., Liden, R.C., Brouer, R.L. and Ferris, G.R. (2012). A meta-analysis of antecedents and consequences of leader-member exchange: integrating the past with an eye toward th future, Journal of Management, Vol. 38 No. 6, pp. 1715-1759.

Ela Unler Oz, Tomru Derekoylu, Sirli Ender, Didem Yuldiz. (2013). What Has Job satisfaction Got Do With Employee Commitment? A Research Study On LMX and Work Attitudes. Journal of Global Strategic Management. Volume 7, Nomor 1, pp 79-94.

Erdogan, B., \& Bauer, T. N. (2014). Leader-member exchange (LMX) theory: The relational approach to leadership. In D. Day (Ed.), Oxford Handbook of Leadership and Organizations pp. 407-433. Oxford: UK: Oxford University Press

Ferdinand, Augusty. (2005). Structural Equational Modelling Dalam Penelitian Manajemen. Semarang : BP.FE. Undip.

Forsyth V. (2010). Group Dynamic (5 ${ }^{\text {th }}$ Edition). U.S.A. Wadshorth Cengage Learning.

Francesco Montani, Francois Coury, Cristian Vandenberghe (2017). Innovating Under Stress : The Role of Comemitment and Leader Member Exchnage. Journal of Business Research. Vol. 5 No. 1 pp. 77. 1-13

Gary Dessler. (2017). Manajemen Sumber Daya Manusia. Penerbit : Salemba Empat. Jakarta Selatan.

Ghozali Imam. (2014). Structural Equation Modelling. Metode Alternatif dengan Partial Least Square (PLS). Semarang : BP. Undip.

Gian Casimir, Yong Ngee Keith Ng, Karen Yuan Wang and Gavin Ooi. (2014). The Relationships Amongst Leader-Member Exchange, Perceived Organizational Support, Affective Commitment, And In-Role Performance : A Social - Exchange Perspective. Ledaership \& Organizational Development Journal. Volume 35 Nomor 5. Pp. 336-385.

Gitosoedarmo Indriyo dan Sudita I Nyoman. (2012). Prilaku Keorganisasian, Edisi Pertama, Cetakan Keempat, Yogyakarta : BPFE.

Hair, J. F., Black, W. C., Babin, B. J., Anderson, R. E., \& Tatham, R. L. (2006). Multivariate data analysis 6th Edition.

Hasibuan, Malayu. (2014). Manajemen Sumber Daya Manusia. Edisi Revisi, Cetakan Ketujuh Belas. Jakarta : Bumi Aksara.

Kenneth J. Harris, K. Michele Kacmar. (2006). Too Much of a Good Thing : The Curvilinear Effect of Leader Member Exchange of Stress. The Journal of Sosial Psychology. Vol. 146 No.1. pp. 65-84.

Kreitner, Kinicki. (2010). Organizational Behavior. New York : McGraw-Hill

Latan Hengky \& Ghozali Imam. (2014). Partial Least Squere, Konsep, Teknik dan Aplikasi, Smart PLS 3.0. Untuk Penelitian Empiris, Edisi 2 Penerbit Semarang : Universitas Diponogoro. 
Made Kerta Adhi. (2016). Tat Twam Asi : Adaptasi nilai kearifan lolal dalam pengentasan kemiskinan cultural. Seminar Nasional Riset Inovatif (Senari) Ke-4 Tahun 2016.

Mangkunegara, Anwar P. (2015). Perencanaan dan Pengembangan Sumber Daya manusia. Bandung : Refika Aditama

Manzoor, R.S. (2011). Effect of Team Work on Employee Performance. The International Journal of Management, Vol.2 No.4 Hal. 110-126

Mathis \& Jackson. (2011). Manajemen Sumber Daya Manusia. Jakarta: PT. Salemba Emban Patria.

Matthew Jason Shaffer. (2016). Leader-Member Exchange As A Predictor Of Leaders Positive Work Outcomes. Doctoral Dissertation Gradaute School University of Tennessee-Knoxville. Vo. 1 Nomor 5 pp. 20-35

Peraturan Pemerintah Republik Indonesia Nomor 46 Tahun 2011 Tentang Penilaian Prestasi Kerja Pegawai Negeri Sipil.

Permen Desa Nomor 4 Tahun 2015 Tentang Pendirian, Pengurusan dan Pengelolaan Serta Pembubaran Badan Usaha Milik Desa.

Permendagri Nomor 39 Tahun 2010 Tentang Badan Usaha Milik Desa Menteri Dalam Negeri Republik Indonesia.

Robbin S.T. \& Judge, Timothy A. (2013). Organizational Behavior. Fiveteenth Edition. New Jersey : Pearson Education.

Sandra, D. (2007). Cara Membangun Tim Impian. Bandung : Penerbit Progressio

Sugiyono. (2015). Metode Penelitian Kuantitatif, Kualitatif dan R\&D.Cetakan 22. Penerbit: Alfabeta, Bandung.

Truckenbrodt, Yolanda B. (2000). Acquisition Review Quarterly (Research) : The Relationship Between LeaderMember Exchange and Commitment and Organizational Citizenship Behavior. Nova Sotheastern University.

Walumba, Mayer, Wang, Workman \& Christensen. (2010). Linking Ethical Leadership to Employee Performance : The Roles of Leader-Member Echange, Self - Efficacy, and Organizational Identification. Organizational Behavior and Human Decision Processes.

Wang D \& Chen Z. X. (2005). Leader-Member Exchange As A Mediator Of The Relationship Between Transformational Leadership And Follower" Performance And Organizational Citizenship Behavior. The Academy Of Management Journal. Vol. 48. No.3 Pp. 420-432

West, Michael. (2012). Kerja Sama Yang Efektif. Cetakan Kelima. Penerjemah : Srikandi Waluyo. Yogjakarta : Penerbit Kanisius.

Yukl, G. (2010). Kepemimpinan Dalam Organisasi. Edisi Ke 5. Jakarta : PT. Indeks.

Article Information (Supplementary)

Conflict of Interest Disclosures:

The authors declare that they have no significant competing financial, professional or personal interests that might have influenced the performance or presentation of the work described in this manuscript.

Copyrights Holder: <Ketut Sudarnaya $><2021>$

First Publication Right: BISMA The Journal of

Counseling

http://dx.doi.org/10.23887/bisma.v4i1

Open Access Article | CC-BY Creative Commons Attribution 4.0 International License.

Word Count:

@creative 